の切離縁間にかけ, これを上下に開排し, 甲状腺を露 出する. 頸部の形に適合し, かつ術者の邪魔になら奷 よう工夫した. おるにバセドウ病と甲状腺癌の手術に 用いる. 甲状腺癌の頸部リンパ節郭清に際しては, 右 側郭清用と左側郭清用の 2 種類を使い分ける.

2. 結禁糸輸送器: 従来の丸田式輸送器は血管の二 重結禁に欠かせない器械であるが，大きすぎる．われ われのモスキート止血針子を改造した小型輸送器は微 細血管の処理に最適である。

3. バセドウ病の残存量を評価するモデル：青銅製 で残存甲状腺に似せた紡錐形をしており，1 $\mathrm{g}$ から $6 \mathrm{~g}$ までの種々な大きさのモデルと比較し, 残存量の評価 ができる.

\section{7. 新しい手術野展開機構}

東京健生病院 外科

赤星良

瑞穂医科工業

根本達

1 手術のスタッフ編成には $3 \sim 4$ 名の医師を必要と するが，昼夜を問わぬ手術において要員の確保は必ず しも容易ではない，さらに長時間一定に鈎を保持する ことが人力では困難な場合も多く，特に吊り上げ開創 用には古くから幾多の器械が考案されてきた.

しかし第 2 助手の作業の多くを代行しうる装置の実 現は遅れて居り, 理由として肝などを圧排した際, 呼 吸運動に追従する能力を兼備することは，固定性と柔 軟性といら一見矛盾した要因への解答である点があげ られる。

当外科では1977年から術野展開機構の開発にとり組 み，主として腹部手術において，

（1）既製の鉤などを取つけて術野に任意の位置角度 で固定せしめることができ, 肋骨弓の強い吊り上げ固 定が可能であると同時に，肝などを圧排した際に呼吸 運動に追従する能力を具えた支持装置, 及び同装置を 骨盤腔内手術その他にも利用するための補助器具,

(2) 開創器などに取つけて臟器を下方に（下腹部手 術の際は上方に）圧排するに適した圧排器及びその支 持装置から成る機構を製作使用しており，第23回消化 器外科学会総会で発表した. 今回瑞穂医科工業 $\mathrm{KK}$ K おいて製品試作が一定の段階に到達したのでその内容 で報告する.

上方からの支持装置は手術台にフレイムを組みこれ に 2 部から成るアームと関節機構で隇菌布を介してク ランプで固定し，追従機構としてアーム部基部に回転
軸を設け, 重力の分圧が患者の上背方に向うようにし たものである、この装置はそのままで強い吊り上げ能 力を持っている. 下方からのものも基本構造は同様で 手指を模した圧排器具を使用した.

当外科に於て約 750 例に開発各段階の装置が使用さ れた. 到達点に於ては術野の展開, 強い挙上位固定, 呼吸運動への追従性はともに良好であり，器械の優位 な点も明らかとなった.この間を通じて同装置使用に よる事故は皆無であった．今後製品化を進める中でよ り高性能なものを生み出したいと考える.

\section{8. 器械縫合を用いる肺生検用鉗子の試作}

東海大 外科 (I) 正津 晃井上宏司 小川純一

泉工医科工業 牛久保雅一

従来肺生検は通常の開胸下に，手縫いによる病変部 肺実質の部分切除が一般的であった。しかし生検を要 する肺実質は，コンプライアンスが低いため，術後の エアリークが比較的長時間持続することが多く，胸部 外科専門医のいない病院では，実施されることが少な かった・診断不明のび漫性肺疾患が増加しつつある今 日，手技が容易，確実な肺生検法を確立することは， 本法普及のため重要と考えている.

われわれは現在までに，気管支断端開鎖，肺部分切 除, 肺分葉不全の切離に, 器械縫合器を用いて良好な 結果を得ているので，この経験を生かして，今回新し い器械觡合を用いる肺生検針子を試作した.

この鎮子は食道縫合器を改良したもので，先端は $\mathrm{V}$ 字型になっており，2 列のステープルと切離メスが組 みこまれている.切離可能な肺実質は, 3 辺の長さが $1.5,1.5,1.0 \mathrm{~cm} の \mathrm{~V}$ 字型で, ステープルの大きさは 各辺の長さが $0.48,0.4,0.48 \mathrm{~cm}$ U字型で, 採取可 能な肺実質の厚みは，肺を虚脱させた状態で0.8 2.3 mmである.

現在は開胸して肺実柕の採取を行っているが，将来 はこれを改良，小型化して，患側肺をブロッカ付気管 内チューブで虚脱させた後， $3 \mathrm{~cm}$ の皮膚切開を行い， 胸腔鏡で採取部位を確認, この鉗子で肺生検を行う方 法へ進みたいと考えている. 